\title{
From Stage to Virtual: Cultural Strategy of Panggung Kahanan Amidst The Covid-19 Pandemic
}

\author{
Suharyo $^{1 *}$, Khothibul Umam ${ }^{1}$, Fajrul Falah ${ }^{1}$, and Gregorius Tri Hendrawan Manurung ${ }^{1}$ \\ ${ }^{1}$ Department of Indonesian Literature, Faculty of Humanities, Diponegoro University, Semarang - \\ Indonesia
}

\begin{abstract}
The research aimed to investigate the event of Pangung Kahanan and its cultural strategy amidst the Covid-19 pandemic. The method used in the research was the Sociology of Art approach, focusing on the event and artwork productions during the three editions of Panggung Kahanan. The data were collected from the interviews with the artists involved in Panggung Kahanan and the committee/team of Panggung Kahanan. The data collection methods used in the research were observation and in-depth interviews. The observation method covered the data related to the production of Panggung Kahanan event. The in-depth interview method covered the data related to the concept of the Panggung Kahanan event. The analytical method used in the research was to investigate how far Panggung Kahanan impacted the art ecosystem in Central Java and what kind of cultural strategy was applied for the resilience of Indonesian art and culture amidst the Covid-19 pandemic. The research showed that Panggung Kahanan could model an art and cultural event amidst social distancing and strict health protocol. Amidst the pandemic, preserving this kind of cultural strategy becomes essential.
\end{abstract}

\section{Introduction}

The Covid -19 pandemic that broke out throughout the world in 2020 had an unbelievable effect on every aspect of life, including the performing arts field in Indonesia. Performing arts in which the characters rely on the audience and live cultural events devastated the Covid19 pandemic. Holding performances on stage becomes impossible with all kinds of social distancing. Various performing arts genres faced the same problem, including theatre, music, and dance, from traditional to modern arts.

The Koalisi Seni recorded that until early April 2020, there were ten postponed film production processes and releases, 40 concerts, tours, and music festivals; eight exhibitions at fine arts museums; three dance performances; and nine theatre performances, pantomime, and puppet [1]. The number kept rising that 234 art shows were cancelled or postponed, 37.000 artists or art workers lost their income amidst the pandemic, and 189.586 art and creative workers, from musicians, stage crews, and film crews, were fired and sent home [2].

* Corresponding author: suharyo@lecturer.undip.ac.id 
As one of the epicentrse of arts in Indonesia, Central Java faced a problem when the performing arts workers could no longer hold any performance. Without any performance, the artists automatically no longer had any income. To overcome the problem, they conducted various kinds of experiments and adaptations. Panggung Kahanan became one of the events they held to overcome it. It was a virtual event in the official residence of the Governor of Central Java, Ganjar Pranowo, during Ramadan 2020. It also became a fundraising event for the artists in Central Java [3]. In the second edition, Panggung Kahanan took place in TVRI Central Java in 10 episodes. Subsequently, the 6 (six) towns, including Kendal, Pati, Magelang, Banyumas, Surakarta, and Pekalongan became the place to hold the last edition of Panggung Kahanan in turn, during Ramadan 2021.

\section{Literature Review}

For a long time, performing arts have a significant position among the people of Indonesia. People use various kinds of performing arts in religious rites, traditional ceremonies, expressions of social and political criticism, and they infiltrate everyday life. It can also function as an appointment of power, strengthen the social relationship, and celebrate collective values [4].

Performing arts have a unique atmosphere, an "occurrence" where interaction between performers (read: artists) and the audience occurs. There is a live interaction between them; they see and feel each other in the same atmosphere. Nothing can replace it in the virtual stage [5].

Given the overview, it is utterly understandable that performing arts are one of the art genres that is most affected by the Covid-19 pandemic. The absence of stages and performances because of the social distancing hit the vitality of the performance artists. Dadang Dwi Septiyan conducted one of the research regarding performing arts. Dadang's research concluded that the Covid-19 pandemic harmed the continuity of music culture. The changing of media into the virtual performance gave rise to a distance between the performers and audience, reducing the interaction among people that led to dehumanization [6].

Robby Hidajat et al. also researched the impact of social distancing policy on the art workers and creative industry in East Java, Yogyakarta, and South Sumatra. The research showed that $13.1 \%$ of art workers lost their income, $26.3 \%$ were hopeless and surrendered, $36.8 \%$ of art workers were incapable of predicting the expected condition, and $52.6 \%$ were waiting for government assistance. From the research, it can be inferred that the art workers had no experience in facing a social disaster; when the turnover went up, they unknowingly invested. When the production decreased, causing the turnover decrease, they did not have an alternative and thus giving rise to a new poor group from the creative sector amidst the Covid-19 pandemic [7].

Different from the two research above, this research will focus on how a pandemic eventually made the performing artists in Central Java experimented and adapted in behalf of survival and cultural resilience.

\section{Research Method}

The research was included in the category of field research. The basis of the research was sociology, which worked based on qualitative research. The approach used in the research was Sociology of Art, which notably discussed or examined people with specific involvement in art activities and other people outside art activities who were involved in the cultural phenomenon that influenced the art activities. The principal study was the people as connoisseurs, observers, reviewers, researchers, educators (consumers), and organizers of 
arts as the components of the art creation process $[8,9,10]$. The research data resulted from interviews with the artists involved in Panggung Kahanan and the committee/team of Panggung Kahanan. The data collection methods used in the research were observation and in-depth interviews. The observation method covered the data regarding the production of Panggung Kahanan event. The in-depth interview method covered the data related to the concept of Panggung Kahanan event. The analytical method used in the research was to investigate how far the event of Panggung Kahanan impacted the performing arts ecosystem in Central Java and what kind of cultural strategy applied for the resilience of art and culture amidst the Covid-19 pandemic.

\section{Panggung Kahanan: From Stage to Virtual}

\subsection{First Edition: The First Momentum of Pandemic and Art Donation}

The The Indonesian government officially announced the case of a positive Covid-19 patient on March 2nd, 2020. However, as an Epidemiologist of the University of Indonesia, Pandu Riono stated that the SARS-CoV-2 virus as the cause of Covid-19 had entered since early January 2020 [11]. Following the pandemic announcement, the government enforced social distancing as the anticipation from the spreading of Covid-19.

The social distancing undoubtedly gave rise to many problems in every aspect of social life, from the economy to education. Art and culture were no exception. When the government announced the period of social distancing, people prepared to face Ramadan that came by the end of April. Ramadan is a special month for Indonesians, even for non-Muslims. Many cyclicalities of needs and economy happened during Ramadan until Eid Al-Fitr.

During that momentum, the first edition of Panggung Kahanan was present. It was first held on May 4th, 2020, and ended on May 19th, 2020, at Puri Gedeh (the official residence of the Governor of Central Java). On his YouTube channel and Facebook account, Ganjar Pranowo (the Governor of Central Java) aired the whole event that included 8 (eight) episodes. This first edition involved around 30 artists and art groups, from traditional artists, theatre performers, musicians, comics, fine artists, and writers. The majority of the artists came from Semarang and the ex-Recidency of Semarang. The policy was inseparable from the strict social distancing; hence the artists who directly participated as much as possible came from within the City of Semarang. The event facilitated the artists from outside of Semarang with the work submission of recorded media in video works, either a recorded performance or a short movie.

The first edition also opened a donation for the artists affected by the Covid-19 pandemic. People could donate through the committee's account. They distributed the donation money to various art workers in Central Java in a cash transfer scheme, working grants, and event production.

\subsection{Second Edition: More Aesthetic and Innovative}

Entering late 2020, no sign that the Covid-19 pandemic was going to be over. The art and culture life were stagnant and tended to collapse. Therefore, on October 30th, 2020, Panggung Kahanan was held in a new format. The new format was more mature, with more innovative concepts, a more aesthetic artistic stage, and the guests who accommodated the artists of Central Java more evenly. 
The second edition of Panggun Kahanan was held at TVRI Central Java studio. The practical consideration of facilities and infrastructure was inseparable from the selection of event location. At least in Semarang, TVRI Central Java had the only studio that was proper and able to produce a recorded performing art in the national class concept.

The second edition of Panggung Kahanan was no different from the first edition. The fundamental difference was on the artistic concept that was more mature according to television standards. It involved the performance artists, from traditional dance, traditional and contemporary puppet, indie bands across genres, short movies, dramatic reading, and fine artists and designers who designed the artistic stage in every episode. Besides, since Bank Jateng sponsored the event, there was also "Lapak Ganjar", a segment that presented an interview with Micro, Small, and Medium Enterprises assisted by Bank Jateng regarding their tips to face the Covid-19 pandemic.

Generally, the second edition of Panggung Kahanan was more mature in concept and content than the first edition. It could not separate itself from the experience of the first edition event and the facilities and infrastructure of TVRI Central Java studio, which was adequate.

\subsection{The Third Edition: A Means of Art Locality and Fraternity}

The third edition of Panggung Kahanan was the repetition of the first edition, for it occurred during Ramadan as the previous year in 2020. This time, the difference was that it travelled from one town to another, including Kendal, Pati, Magelang, Banyumas, Surakarta, and Pekalongan. The first point was in Kendal on April, 21 st 2021.

The third edition combined the first and second-edition concepts added with the locality aspects of every town. The concept and content of the event still consisted of performances from the musical performers, traditional theaters, traditional comedies, and the musicalization of poetry. "Lapak Ganjar" segment was present, presenting the Micro, Small, and Medium Enterprises of each town.

The locality became the most prominent thing in the third edition of Panggung Kahanan. The selection of the six towns was based on the six ex-residency areas of Central Java and became the representation of the towns in the region. Each town had a unique locality, such as dangdut Pantura (Kendal and Pati), comedy and ketoprak (Pati), Kuda Lumping (Magelang), Begalan (Banyumas), and gambus music (Pekalongan). Specifically for Surakarta, Panggung Kahanan was conceptualized as a tribute to the campursari maestro Didi Kempot, as it was the first anniversary of his death.

In production, the third edition of Pangggung Kahanan was the most complicated, from the preparation to the end of the event. In three weeks, Panggung Kahanan team travelled to six towns with two towns every week on average. The difference in facilities and infrastructure in every town became another challenge. We must admit that the artistic resources in every town were very distinct. It affected the quality of the event and the performances.

\section{Conclusion}

As a cultural event amidst the Covid-19 pandemic, Panggung Kahanan showed success. The event provided an opportunity to the artists and cultural actors and the Micro, Small, and Medium Enterprises to continue getting the economic return. There were hundreds of artists and cultural actors who received cash transfers, working grants, and art and cultural events productions. Panggung Kahanan can be a model to create art and cultural events amidst the social distancing and strict health protocol. Preserving this kind of cultural strategy is essential amidst the pandemic. 


\section{References}

1. L. Safriana, (2020), Tantangan Berat Seniman Pertunjukan di Masa Pandemi Corona, Retrieved from https:/katadata.co.id/muchamadnafi/indepth/5e9a41c87f85e/tantanganberat-seniman-pertunjukan-di-masa-pandemi-corona

2. H. Gumay, (2020), Menyoal Kebijakan Kartu Prakerja untuk Seniman Terdampak Pandemi, Retrieved from https://koalisiseni.or.id/menyoal-kebijakan-kartu-prakerjauntuk-seniman-terdampak-pandemi/

3. W. Fajriah, (2020), Panggung Kahanan, Ajang Donasi untuk Seniman Terdampak Covid19, Retrieved from https://news.okezone.com/read/2020/05/12/512/2212647/panggungkahanan-ajang-donasi-untuk-seniman-terdampak-covid-19

4. B. Hatley, (2014), Pertunjukan Budaya Indonesia Pasca Orde Baru, in Seni Pertunjukan Indonesia Pasca Orde Baru, 3, (2014)

5. S. Dewi, Seni dalam Lipatan Pandemi, (Pidato Seni Dies Natalis Institut Kesenian Jakarta ke-50), 6, (2020)

6. D. D. Septiyan, Perubahan Budaya Musik di Tengah Pandemi Covid-19, in Jurnal Musikolastika: Jurnal Pertunjukan Dan Pendidikan Musik, 2(1), 31-38 (2020)

7. R. Hidajat, S. Wulandari, Y. N. Astuti, M. A. Hasyimy, Pekerja Seni yang Terdampak Pandemi Covid-19 pada Sektor Industri Kreatif di Indonesia, in Jurnal Imaji: Jurnal Seni dan Pendidikan Seni, 18(2), (2020)

8. R. Escarpit, Sosiologi Sastra, 1-2 (2005)

9. S. D. Damono, Sosiologi Sastra: Sebuah Pengantar Ringkas, 3-5 (1978)

10. J. Wolff, The Social Production of Art (Second Edition), 40-48 (1993)

11. E. Pranita, (2020), Diumumkan Awal Maret, Ahli: Virus Corona Masuk Indonesia dari Januari, Retrieved from https:/www.kompas.com/sains/read/2020/05/11/130600623/ diumumkan-awal-maret-ahli--virus-corona-masuk-indonesia-dari-januari 